\title{
Expression of a human polyomavirus oncoprotein and tumour suppressor proteins in medulloblastomas
}

\author{
L Del Valle, J Baehring, C Lorenzana, A Giordano, K Khalili, S Croul
}

The Center for NeuroVirology and Cancer Biology, Temple University, Philadelphia, PA 19122, USA

L Del Valle

K Khalili

Department of Pathology and Laboratory of Medicine, $\mathrm{MCP} / \mathrm{HU}$ School of Medicine, 3300 Henry Ave, Philadelphia, PA 19129, USA

S Croul

Department of Neurology MCP/HU School of Medicine, Philadelphia, PA 19102-1192, USA J Baehring

Department of Pathology, Anatomy, and Cell Biology,

Jefferson Medical College, Philadelphia, PA 19107, USA

C Lorenzan

A Giordano

Correspondence to: Dr Croul

Sidney.Croul@Drexel.edu

Accepted for publication 17 April 2001

\begin{abstract}
Aims-Although the aetiology of medulloblastoma remains elusive, several lines of evidence suggest an association with the human neurotropic polyomavirus JC and its oncoprotein $T$ antigen. The tumour forming properties of $\mathrm{JC}$ virus $\mathrm{T}$ antigen are the result, at least in part, of its ability to bind and inactivate tumour suppressor/ cell cycle regulatory proteins, such as p53 and the retinoblastoma family of proteins. Methods-To examine potential relations between these factors, immunohistochemistry was used to determine associations between the $T$ antigen and the expression of $\mathrm{p} 53$ and the retinoblastoma proteins $\mathrm{pRb}, \mathrm{p} 107$, and $\mathrm{Rb} 2 / \mathrm{p} 130$ in eight medulloblastomas.

Results-Only the three medulloblastomas with $\mathbf{T}$ antigen expression also showed nuclear positivity with antibodies to p53. Although immunohistochemistry detected nuclear labelling for $\mathrm{pRb}$ in five of the cases, the three that were positive for $T$ antigen showed the highest pRb labelling. The retinoblastoma related proteins p107 and $\mathrm{Rb} 2 / \mathrm{p} 130$ were also immunopositive in most $T$ antigen positive medulloblastomas. Double label immunohistochemistry also demonstrated $p 53$ and $p R b$ positivity in the same cells that were $\mathbf{T}$ antigen positive.

Conclusions-These correlations suggest that associations between $T$ antigen and p53 and/or $T$ antigen and $p R b$ occur in some of these tumours. These data provide indirect evidence that JC virus, acting through $T$ antigen, might be involved in the formation and progression of medulloblastoma.

(F Clin Pathol: Mol Pathol 2001;54:331-337)
\end{abstract}

Keywords: medulloblastoma; $\mathrm{T}$ antigen; $\mathrm{p} 53$; retinoblastoma protein

Brain tumours are the most common solid neoplasm of childhood. ${ }^{1}$ Most central nervous system (CNS) malignancies in children are primitive neuroectodermal tumours (PNETs), which account for $6-8 \%$ of all CNS tumours. ${ }^{2}$ These tumours, which include cerebral neuroblastomas, ependymoblastomas, pineoblastomas, and medulloblastomas, have been grouped together because of the young age of the patients in which they occur and their common histological features. ${ }^{34}$ Of the primitive neuroectodermal tumours, medulloblastomas are the most common, accounting for $20 \%$ of all paediatric intracranial neoplasms. ${ }^{5}$

Although the aetiology of these tumours remains elusive, several lines of evidence suggest an association between the human neurotropic polyomavirus JC (JCV) in a large number of these tumours. JCV is known to cause PNETs in experimental models. More than $80 \%$ of neonatal hamsters inoculated intracerebrally, intraperitoneally, or subcutaneously with strains of JCV isolated from progressive multifocal leucoencephalopathy lesions develop a wide range of tumours, including medulloblastomas, neuroblastomas, and pineocytomas. ${ }^{67}$ Although the mechanism of JCV induced neurotumorigenesis is not entirely clear, several lines of evidence point to the involvement of the viral early protein $\mathrm{T}$ antigen in this process. JCV T antigen is found in human and hamster glial cells transformed with JCV DNA. ${ }^{8}$ Transgenic mice that constitutively produce $\mathrm{T}$ antigen under the control of JCV early promoters/enhancers have been shown to develop adrenal neuroblastomas, primitive appearing mesenteric tumours, and medulloblastomas. ${ }^{910}$

In an attempt to delineate the possible contribution of polyoma viruses to the formation of medulloblastomas in humans, we recently investigated a series of these tumours for the presence of JCV DNA and T antigen. ${ }^{112}$ In those cases, most tumours contained JCV sequences. One fourth also expressed $\mathrm{T}$ antigen when assayed immunocytochemically. Because the oncogenic properties of JCV $\mathrm{T}$ antigen result, at least in part, from its ability to bind and inactivate tumour suppressor/cell cycle regulatory proteins, such as $\mathrm{p} 53,{ }^{13-17}$ a correlation may exist between $\mathrm{T}$ antigen and $\mathrm{p} 53$ expression in medulloblastomas. In support of this concept, increased p53 protein values have been reported in these tumours, ${ }^{18}$ despite a low frequency of mutations in the p53 gene. ${ }^{19-22}$

JCV $\mathrm{T}$ antigen is also known to associate with other tumour suppressors such as the retinoblastoma $(\mathrm{Rb})$ family of proteins. ${ }^{14}{ }^{23}$ Although the contribution of $\mathrm{T}$ antigenretinoblastoma gene product $(\mathrm{pRb})$ interactions to JCV induced malignancies remains to be elucidated, one could speculate that this association would result in release of $\mathrm{pRb}$ from $\mathrm{E} 2 \mathrm{~F}$, its normal complex partner. $\mathrm{E} 2 \mathrm{~F}$ is a transcription factor that by stimulating $S$-phase specific genes accelerates G1/S phase entry, 
resulting in a positive effect on cell proliferation. ${ }^{24}{ }^{25}$ Because both $\mathrm{p} 53$ and $\mathrm{pRb}$ operate at least in part through common cell regulatory pathways, it is likely that a $\mathrm{T}-\mathrm{pRb}$ interaction would also indirectly affect p53 related mechanisms of tumorigenesis. ${ }^{26}$

To examine these potential relations in human tumour resection samples, we used immunocytochemistry to determine the contribution of $\mathrm{T}$ antigen to the expression of $\mathrm{p} 53$ and the $\mathrm{Rb}$ proteins in medulloblastomas. Using this approach, we have shown correlations between $\mathrm{T}$ antigen and p53 and between $\mathrm{T}$ antigen and the $\mathrm{Rb}$ proteins. These findings support the hypothesis that JCV, acting through $\mathrm{T}$ antigen, is involved in medulloblastoma formation and/or progression.

\section{Materials and methods}

TISSUE SAMPLES

Eight medulloblastoma samples were obtained from the archives of two Philadelphia institutions: Hahnemann University Hospital and Saint Christopher's Hospital for Children. All samples were formalin fixed and paraffin wax embedded. Formalin fixed and paraffin wax embedded control tissues obtained from the Hahnemann University Hospital archives included 10 samples of normal postmortem cerebellum spanning the ages from birth to 70 years, and two normal adult lung specimens. Additional formalin fixed paraffin wax embedded controls included JCV induced PNETs in Syrian hamster brain.

Sections ( $4 \mu \mathrm{m}$ thick) of the medulloblastoma specimens were stained with haematoxylin and eosin to confirm tissue diagnoses. Of the tumour samples, four were available in large enough quantities to allow DNA extraction and polymerase chain reaction (PCR) analysis for JCV DNA. This was performed with methods reported previously ${ }^{12}$ to ascertain whether sequences were from the $\mathrm{N}$-terminal portion of the early genome, the C-terminal portion of the early genome, or the VP1 portion of the late genome.

\section{IMMUNOHISTOCHEMICAL ANALYSIS}

Immunohistochemistry was performed by dewaxing the sections in xylene, followed by rehydration and non-enzymatic antigen retrieval in $0.01 \mathrm{M}$ sodium citrate buffer $(\mathrm{pH} 6.0)$ at $95^{\circ} \mathrm{C}$ for 40 minutes. After cooling to room temperature (approximately 20 minutes), slides were rinsed and endogenous peroxide was quenched by incubation in $\mathrm{MeOH} /$ $3 \% \mathrm{H}_{2} \mathrm{O}_{2}$ for 20 minutes. This was followed by a wash in phosphate buffered saline (PBS) and blocking in PBS $/ 0.1 \%$ bovine serum albumin plus $5 \%$ normal horse serum for two hours at room temperature. Slides were then incubated overnight with primary antibodies. To detect $\mathrm{T}$ antigen, a mouse monoclonal antibody to the SV40 $\mathrm{T}$ antigen that crossreacts with JCV $\mathrm{T}$ antigen (pAb416; Oncogene Science, Cambridge, Massachusetts, USA) was used at a $1 / 100$ dilution. p53 was detected with a mouse monoclonal antibody that recognises both wild-type and mutated forms of the protein (D0-7; Dako, Carpinteria, California, USA;
$1 / 100$ dilution). $\mathrm{pRb}$ was detected with a mouse monoclonal antibody to the human protein (14001A; Pharmigen; 1/100 dilution) and its family members p107 and Rb2/p130 were detected with rabbit polyclonal antibodies (provided by A Giordano, p107 and Rb2/p130; both $1 / 1000$ dilution). Positive controls for $T$ antigen were paraffin wax embedded tumours from Syrian hamsters intracerebrally inoculated with JCV. For p53, paraffin wax embedded sections of human astrocytomas were used. Human adult lung sections including bronchial epithelium served as positive controls for $\mathrm{pRb}, \mathrm{p} 107$, and $\mathrm{Rb} 2 / \mathrm{p} 130 .{ }^{27}$ Negative controls consisted of tissues incubated in buffer without primary antibody. Primary antibodies were detected with biotinylated antimouse or antirabbit secondary antibodies, avidin-biotin peroxidase complex, and diaminobenzidine chromagen, according to manufacturer's instructions (Vectastain Elite ABC Peroxidase Kit; Vector Laboratories Burlingame, California, USA). After a light counterstain with haematoxylin, sections were dehydrated and coverslipped with Permount.

Double label immunohistochemistry for $\mathrm{T}$ antigen-p53 and $T$ antigen-pRb colocalisations was performed by sequential applications of the primary antibodies to the same tissue section, which were both revealed by ABC systems but with different chromagens. After incubation of the first primary antibody, secondary antibody and ABC incubations were performed as described above, followed by development with DAB. The tissue was then taken back to buffer and blocking reagent, incubated in the second primary antibody overnight, followed by secondary antibody and ABC. The second chromagen used was Vector red, which was used according to the manufacturer's directions.

Each slide was examined independently by two microscopists (SC and LDV) for tumour type by haematoxylin and eosin morphology and the presence or absence of immunohistochemical stain product. In all tumours that stained positively, the percentage of immunopositive cells was calculated by counting the total number of tumour nuclei and the number of immunopositive nuclei in five random, noncontiguous fields at $\times 1000$ magnification (an average of 73 nuclei/field). As listed in table 1 , these raw data were used to calculate an average percentage of positive cells and the SD of that percentage for each positive immunostain. In the case of double stains, this analysis was extended to include the percentage of double positive nuclei in each section. This was compared with the "expected" percentage of double positive nuclei calculated as the product of single positive nuclei. Thus, in the case of $\mathrm{T}-\mathrm{p} 53$ double staining, the expected percentage of $\mathrm{T}-\mathrm{p} 53$ positive nuclei would be the product of the percentage of $\mathrm{T}$ positive and the percentage of p53 positive nuclei. This expected percentage would represent a chance process, whereas observed percentages clearly different from expected would represent a process not determined by chance. The double 
Table 1 Patient data and PCR for $\mathcal{F C}$ virus ( $(F C V)$ in eight medulloblastomas

\begin{tabular}{|c|c|c|c|c|}
\hline Case & Patient age/sex & Histology & Tumour location & $\mathcal{F C V} P C R$ \\
\hline 1 & 5 years $/ M$ & Neuroblastic medulloblastoma & Posterior fossa & $\begin{array}{l}\text { N-terminal + } \\
\text { C-terminal + } \\
\text { VP1 + }\end{array}$ \\
\hline 2 & 12 years $/ M$ & Neuroblastic medulloblastoma & Left cerebellar hemisphere & $\begin{array}{l}\text { N-terminal + } \\
\text { C-terminal - } \\
\text { VP1 + }\end{array}$ \\
\hline 3 & 15 years $/ M$ & Desmoplastic medulloblastoma & Left cerebellar hemisphere & $\begin{array}{l}\text { N-terminal + } \\
\text { C-terminal - } \\
\text { VP1 - }\end{array}$ \\
\hline 4 & 9 years/F & Desmoplastic medulloblastoma & Posterior fossa & $\begin{array}{l}\text { N-terminal - } \\
\text { C-terminal + } \\
\text { VP1 + }\end{array}$ \\
\hline 5 & 10 years $/ M$ & Classic medulloblastoma & Cerebellum & - \\
\hline 6 & 11 years/M & Classic medulloblastoma & Cerebellum & - \\
\hline 7 & 4 years/M & Classic medulloblastoma & Cerebellum & - \\
\hline 8 & 10 years $/ M$ & Classic medulloblastoma & Posterior fossa & - \\
\hline
\end{tabular}

stains for $\mathrm{T}$ antigen and $\mathrm{pRb}$ were analysed similarly.

For statistical analysis, the single label immunohistochemistry results for $\mathrm{T}$ antigen positive versus $T$ antigen negative groups were compared by the one tailed continuity corrected $\chi^{2}$ method (because of the small number of samples), with the $\mathrm{p}$ value for significance set at $\leqslant 0.05$. In cases where this test did not return significance, the normal $\chi^{2}$ test and the $t$ test were also applied. In the case of double label immunohistochemistry, the paired $t$ test was used to compare observed with expected percentages in each microscopic field analysed.

\section{Results}

The 10 specimens of cerebellum obtained from normal paediatric and adult necropsies failed to show positive staining for $\mathrm{T}$ antigen or $\mathrm{p} 53$. Antibodies to $\mathrm{pRb}, \mathrm{p} 107$, and $\mathrm{Rb} 2 / \mathrm{p} 130$ produced nuclear labelling in most of the Purkinje cells and rare granule cells. In the three specimens of the youngest children whose cerebellum contained an external granule cell layer, these cells also displayed prominent nuclear labelling for $\mathrm{pRb}, \mathrm{p} 107$, and $\mathrm{Rb} 2 / \mathrm{p} 130$.

The clinical details of the eight tumours analysed are presented in table 1 . They all occurred in the cerebellums of children and were medulloblastomas. Histologically, the three major subtypes-classic, neuroblastic, and desmoplastic medulloblastomas-were represented. Figure 1A shows case 1 stained with haematoxylin and eosin and immunohistochemically for synaptophysin.

Of the four tumours analysed by PCR, all showed JCV sequences (table 1 ). Case 1 was positive for all sequences analysed. Cases 2 and 4 were positive for two of the three sequences
A

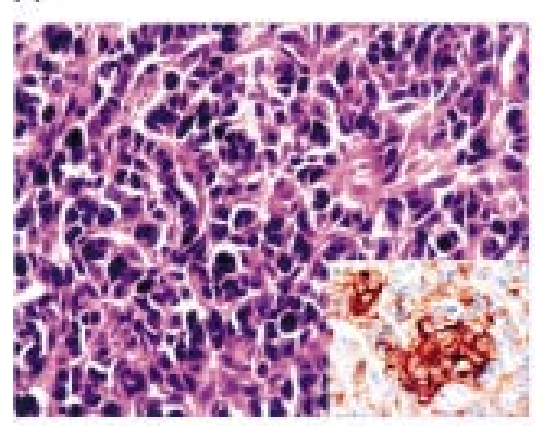

D

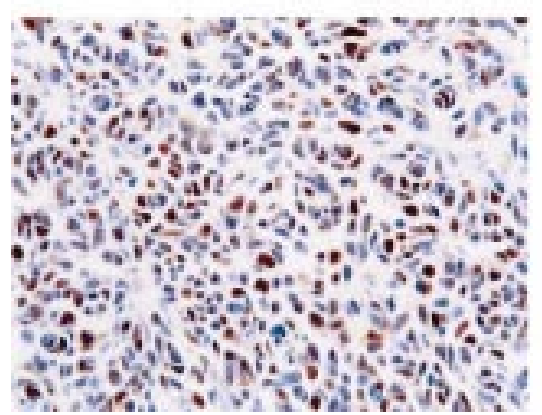

B

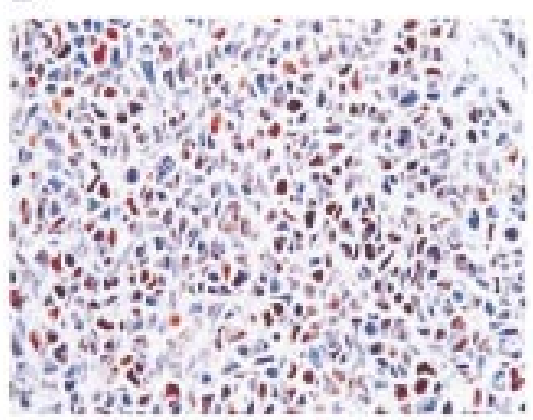

E

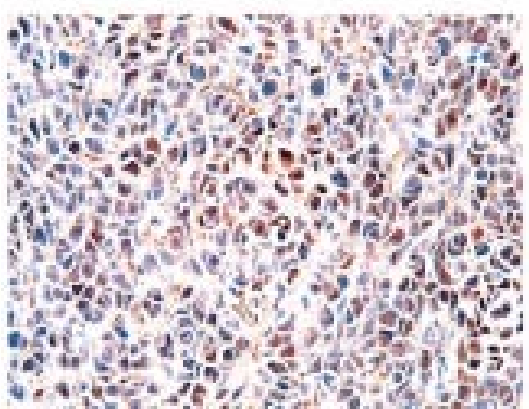

C

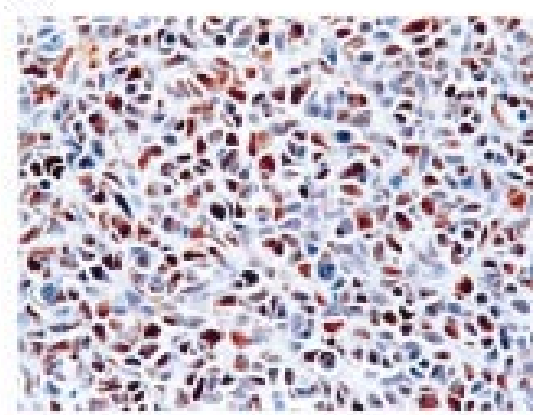

$\mathrm{F}$

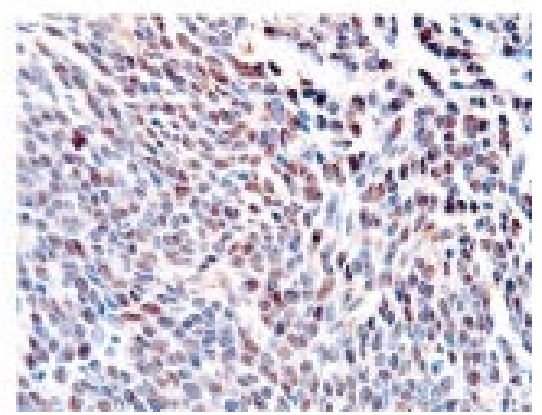

Figure 1 Labelling of a medulloblastoma with antibodies to T antigen, $p 53, p R b, p 107$, and Rb2/p130. (A) Haematoxylin and eosin stained sections of case 1 show the characteristic morphology of a medulloblastoma with a high nuclear to cytoplasmic ratio, dense nuclear chromatin, and cytoplasmic extensions with occasional rosette formation. Synaptophysin immunostaining further defines the neural phenotype of the tumour cells (inset). (B) T antigen staining shows nuclear positivity in approximately one third of the cells. (C) p53 nuclear positivity is found in tumour nuclei. Nuclear positivity for (D) $p R b$ and its related proteins $(E)$ p107, and $(F)$ Rb2/p130. All original magnifications, $\times 40$. 
Table 2 Single label immunohistochemistry

\begin{tabular}{|c|c|c|c|c|c|}
\hline & $T$ antigen & $p 53$ & $p R b$ & p107 & $R b 2 / p 130$ \\
\hline Case & $\begin{array}{l}\text { No. positive/no. counted } \\
(\% ; S D)\end{array}$ & $\begin{array}{l}\text { No. positive/no. counted } \\
(\% ; S D)\end{array}$ & $\begin{array}{l}\text { No. positive/no. counted } \\
(\% ; S D)\end{array}$ & $\begin{array}{l}\text { No. positive/no. counted } \\
(\% ; S D)\end{array}$ & $\begin{array}{l}\text { No. positive/no. counted } \\
(\% ; S D)\end{array}$ \\
\hline 1 & $135 / 325(41.26 \% ; 3.91)$ & $74 / 433(17.30 \% ; 4.86)$ & $125 / 492(25.66 \% ; 4.30)$ & $158 / 375(42.01 \% ; 5.21)$ & $105 / 492(1.38 \% ; 3.46)$ \\
\hline 2 & $105 / 474(22.41 \% ; 5.77)$ & $207 / 439(47.40 \% ; 4.87)$ & $199 / 421(46.97 \% ; 4.72)$ & $64 / 342(18.56 \% ; 6.70)$ & $49 / 374(13.07 \% ; 11.75)$ \\
\hline 3 & $112 / 311(6.17 \% ; 8.42)$ & $63 / 316(19.62 \% ; 5.03)$ & $147 / 358(40.75 \% ; 5.78)$ & - & $22 / 273(8.08 \% ; 2.23)$ \\
\hline 4 & - & - & $46 / 421(10.62 \% ; 3.46)$ & - & - \\
\hline 5 & - & - & $23 / 489(4.56 \% ; 1.83)$ & - & - \\
\hline 6 & - & - & $14 / 318(4.60 \%: 2.01)$ & - & - \\
\hline 7 & - & - & - & - & - \\
\hline 8 & - & - & - & - & - \\
\hline
\end{tabular}

(one early and one late each). Case 3 was positive only for the $\mathrm{N}$-terminal portion of the early genome. It is difficult to analyse these data because all tumours analysed showed some portion of JCV genome. Nonetheless, it is useful to note that the one tumour that was positive for all three regions of JCV (case 1) expressed $\mathrm{T}$ antigen in the greatest percentage of nuclei (see below)

Table 2 shows data from the single label immunohistochemical analysis of the tumours. Three of the eight tumours were positive for $\mathrm{T}$ antigen and five were negative. The percentage of $\mathrm{T}$ antigen positive nuclei in these three cases ranged from $6.17 \%$ (case 3) to $41.26 \%$ (case 1). Figure $1 \mathrm{~B}$ shows a characteristic $\mathrm{T}$ antigen positive field from case 1 .

The sections stained with the antibody to p53 were positive in all three tumours that were $\mathrm{T}$ antigen positive (cases $1-3$ ), ranging from $17.30 \%$ to $47.40 \%$ of nuclei. None of the tumours that were $\mathrm{T}$ antigen negative (cases 4-8) showed p53 positivity. A positive immunoproduct for $\mathrm{p} 53$ is shown in fig $1 \mathrm{C}$ (case 1). Using the continuity corrected $\chi^{2}$ test, there is a clear difference in the p53 positivity of $\mathrm{T}$ antigen positive versus negative groups ( $\mathrm{p}=0.038$, two tailed test; $\mathrm{p}=0.019$, one tailed test).

The antibody to $\mathrm{pRb}$ stained tumour nuclei in six of the eight cases, with positive nuclei ranging from $4.56 \%$ (case 5) to $46.97 \%$ (case 2). A region from case 1 similar to that illustrated in fig $1 \mathrm{~A}$ is shown in fig $1 \mathrm{D}$ stained for $\mathrm{pRb}$. With both the continuity corrected and standard $\chi^{2}$ methods, there is no significant difference in $\mathrm{pRb}$ positivity between the groups of $\mathrm{T}$ antigen positive and negative tumours. However, $\mathrm{pRb}$ positivity in the $\mathrm{T}$ positive cases ranged from $25.66 \%$ to $46.97 \%$, whereas $\mathrm{T}$ negative cases ranged from $4.56 \%$ to $10.62 \%$. Applying the $t$ test instead and counting the negative stained cases as $0, p=0.025$ (two tailed test) and 0.0125 (one tailed test).

Staining with p107 was found in cases 1 and 2 , which demonstrated nuclear immunopositivity in $42.01 \%$ and $18.56 \%$ of cells, respectively. Case 1 is used to illustrate p107 immunostaining (fig 1E). These results are not significant with the continuity corrected $\chi^{2}$ test, but return a $\mathrm{p}=0.035$ (two tailed test) and $\mathrm{p}=0.0125$ (one tailed test) with the standard method.

In the case of $\mathrm{Rb} 2 / \mathrm{p} 130$, all the $\mathrm{T}$ antigen positive tumours again demonstrated nuclear immunoreactivity $(8.08-13.07 \%)$, whereas the $\mathrm{T}$ antigen negative tumours did not. Once again, positive immunostaining is demonstrated for case 1 (fig $1 \mathrm{~F}$ ). Using the continuity corrected $\chi^{2}$, these results are the same as those for $\mathrm{p} 53(\mathrm{p}=0.038$, two tailed test; $\mathrm{p}=0.019$, one tailed test) and are significant.

In several of the $\mathrm{T}$ antigen positive tumours, it was noted that the same populations of cells appeared to exhibit positivity for $\mathrm{T}$ antigen, $\mathrm{p} 53$, and $\mathrm{pRb}$. This observation was pursued further with double label immunohistochemistry to determine whether the same cells expressed $\mathrm{T}$ antigen, $\mathrm{p} 53$, and $\mathrm{pRb}$. The results are illustrated in fig $2 \mathrm{~A}, \mathrm{~B}$. In table 3 , the percentage of cells that were double immunopositive for $T$ antigen-p53 and $T$ antigen $-\mathrm{pRb}$ are compared with the percentages predicted from the positivity for $\mathrm{T}$ antigen, $\mathrm{p} 53$, and $\mathrm{pRb}$
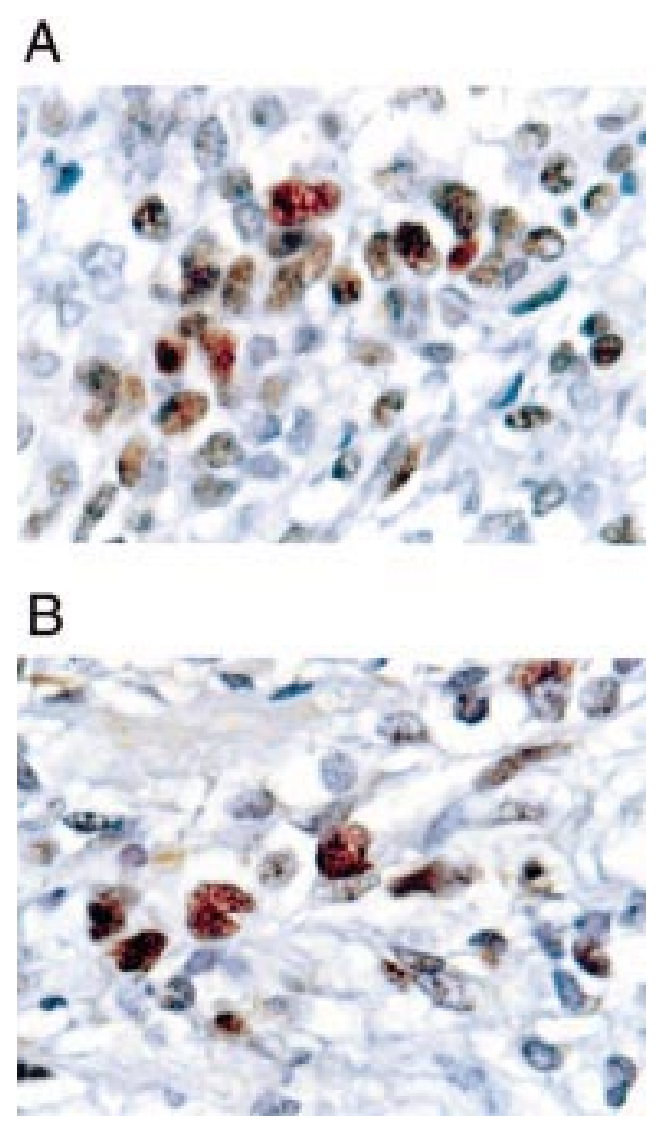

Figure 2 Double label immunohistochemistry of tumour nuclei with antibodies to $T$ antigen, $p 53$, and $p R b$. (A) In case 1, nuclei with immunopositivity for $T$ antigen (brown with $D A B$ as chromagen) are also immunopositive for $p 53$ (Vector red chromagen). (B) $T$ antigen positive nuclei of case 1 (DAB chromagen) are also positive for $\mathrm{pRb}$ (Vector red chromagen). All original magnifications, $\times 100$. 
Table 3 Double label immunohistochemistry

\begin{tabular}{|c|c|c|c|c|}
\hline & $T-p 53$ positive & Predicted & $T-p R b$ positive & Predicted \\
\hline & $\begin{array}{l}\text { No. p53 positive/no. T positive } \\
(\% ; S D)\end{array}$ & $\begin{array}{l}\text { No. } p 53 \text { positive also } T \text { positive } \\
(\% T-p R b \text { positive; } S D)\end{array}$ & $\begin{array}{l}\text { No. } p \text { Rb positive/no. T positive } \\
(\% ; S D)\end{array}$ & $\begin{array}{l}\text { No. } p 53 \text { positive also } T \text { positive } \\
(\% T-p R b \text { positive; } S D)\end{array}$ \\
\hline Case 1 overall & $56 / 173(33.29 \% ; 6.86)$ & $34 / 173(19.78 \% ; 5.30)$ & $34 / 66(52.42 \% ; 6.70)$ & $16 / 66(24.66 \% ; 11.52)$ \\
\hline Field 1 & $13 / 36$ & $9 / 36$ & $8 / 16$ & $4 / 16$ \\
\hline Field 2 & $9 / 23$ & $5 / 23$ & $7 / 12$ & $2 / 12$ \\
\hline Field 3 & $10 / 39$ & $6 / 39$ & $7 / 16$ & $3 / 16$ \\
\hline Field 4 & $11 / 42$ & $10 / 42$ & $6 / 12$ & $3 / 12$ \\
\hline Field 5 & $13 / 33$ & $4 / 33$ & $6 / 10$ & $4 / 10$ \\
\hline Case 2 overall & $29 / 59(49.19 \% ; 6.70)$ & $28 / 59(48.83 \% ; 8.20)$ & $22 / 39(58.00 \% ; 13.04)$ & $17 / 39(43.21 \% ; 5.44)$ \\
\hline Field 1 & $4 / 7$ & $3 / 7$ & $3 / 6$ & $3 / 6$ \\
\hline Field 2 & $4 / 10$ & $4 / 10$ & $6 / 10$ & $4 / 10$ \\
\hline Field 3 & $8 / 15$ & $9 / 15$ & $4 / 5$ & $2 / 5$ \\
\hline Field 4 & $8 / 16$ & $7 / 16$ & $4 / 8$ & $4 / 8$ \\
\hline Field 5 & $5 / 11$ & $6 / 11$ & $5 / 10$ & $4 / 10$ \\
\hline Case 3 overall & $13 / 22(60.10 \% ; 7.02)$ & $4 / 22(18.05 \% ; 4.38)$ & $33 / 37(89.03 \% ; 10.08)$ & $12 / 37(29.04 \% ; 8.64)$ \\
\hline Field 1 & $4 / 7$ & $2 / 7$ & $6 / 6$ & $2 / 6$ \\
\hline Field 2 & $2 / 3$ & $1 / 3$ & $9 / 11$ & $5 / 11$ \\
\hline Field 3 & $3 / 5$ & $1 / 5$ & $5 / 6$ & $2 / 6$ \\
\hline Field 4 & $2 / 4$ & $1 / 4$ & $4 / 5$ & $1 / 5$ \\
\hline Field 5 & $2 / 3$ & $1 / 3$ & $9 / 9$ & $3 / 9$ \\
\hline
\end{tabular}

alone. This is shown for each case overall and, in addition, in each of the fields counted.

In the case of p53 double staining, the field counts in cases 1 and 3 are fairly consistent, with all five counted fields showing greater positive percentages than predicted. These are significant by the paired $t$ test $(\mathrm{p}<0.05$ for case 1 and $p<0.01$ for case 3 ). Case 2 shows almost no pattern of positive staining because two cases demonstrate greater positive percentages than predicted, two are less than predicted, and one is equal to that predicted. This result is not significant by the paired $t$ test.

All the fields of cases 1 and 3 counted showed a greater number of $\mathrm{T}$ antigen $-\mathrm{pRb}$ positive cells than predicted ( $\mathrm{p}$ values $<0.01$ by the paired t test). In Case 2 , the pattern is not quite as consistent (four of five are in the hypothesised direction) and the result is not significant.

\section{Discussion}

We used immunohistochemistry in a series of medulloblastomas to demonstrate that p53 overexpression occurs in the same tumours as the expression of the polyoma oncoprotein $\mathrm{T}$ antigen. Similarly, the expression of the retinoblastoma gene product $\mathrm{pRb}$ and the related proteins $\mathrm{p} 107$ and $\mathrm{Rb} 2 / \mathrm{p} 130$ is greatest in the $\mathrm{T}$ antigen positive tumours. We also used double label immunohistochemistry to demonstrate $\mathrm{T}$ antigen $-\mathrm{p} 53$ and $\mathrm{T}$ antigen $-\mathrm{pRb}$ colocalisation in the nuclei of three of these tumours, and used a quantitative approach to show that the colocalisation in two of these tumours was not coincidental.

Brain tumours account for $15 \%$ of all childhood neoplasms. They are the most common solid neoplasm of childhood and most malignant CNS tumours in children are primitive neuroectodermal tumours. Medulloblastomas, the primitive neuroectodermal tumours that occur in the cerebellum, are the most common, accounting for $20 \%$ of all paediatric intracranial neoplasms. The peak age of occurrence is 7 years and $70 \%$ of tumours present before the age of $16 .{ }^{15}$ Despite the potential for poor outcome with these lesions, the five year survival for children with medulloblastoma currently stands at $50-70 \%$. The improvement in survival seen in the past three decades is largely attributable to improvements in imaging and surgery, which allow complete or near complete tumour resections in a larger proportion of patients than was previously possible. This has been supplemented by improvements in radiotherapy and chemotherapy. ${ }^{21}$ Despite the clinical importance of this tumour, the aetiology of most medulloblastomas remains elusive.

$\mathrm{JCV}$ is a human neurotropic polyomavirus infecting more than $80 \%$ of the human population early in life, and associated with the subacute demyelinating disease, progressive mulitifocal leucoencephalopathy, in immunosuppressed individuals. ${ }^{28}$ It has been associated with chromosomal damage in infected individuals, ${ }^{29}$ and has also been shown to produce PNETs in several animal systems, both through direct inoculation of whole virus or expression of only the early genes, which include $\mathrm{T}$ antigen. ${ }^{691030}$ At present, the JCV and $T$ antigen serological status of patients with paediatric brain tumours is not well characterised.

To test the hypothesis that JCV might also be associated with PNETs in humans, we recently analysed a series of medulloblastomas for the presence of JCV DNA sequences and T antigen expression. ${ }^{12}$ The PCR analysis of nearly $50 \%$ of those tumours demonstrated sequences of $\mathrm{N}$-terminal $\mathrm{T}$ antigen, C-terminal $\mathrm{T}$ antigen, and VP-1 capsid protein corresponding to regions of both the early and late JCV genome. In addition, $25 \%$ of tumours analysed immunohistochemically for $\mathrm{T}$ antigen expression showed nuclear positivity. These results raise the possibility that activation of the JCV early promoter may be an important event in some medulloblastomas.

The data presented in our current study support that possibility by demonstrating a significant relation between $T$ antigen expression and overexpression of p53 in medulloblastomas. We also present evidence that both $\mathrm{T}$ antigen and p53 may be expressed in the same cells of these tumours. This suggests a $T$ antigen-p53 association in medulloblastomas. Previous studies have shown that p53 mutations are not common 
in medulloblastomas. Although loss of heterozygosity in the region of chromosome 17 that contains the p 53 gene has been reported in $30-40 \%$ of medulloblastomas, ${ }^{213132}$ only $5-10 \%$ of these tumours contain p53 mutations. ${ }^{19} 33$ However, between $40 \%$ and $60 \%$ of medulloblastomas show raised p53 content when studied immunohistochemically ${ }^{18}{ }^{34}$ In light of the low frequency of p53 mutations, most tumours with immunocytochemical positivity for $\mathrm{p} 53$ must overexpress the wild-type protein. It is also of interest that high p53 expression in medulloblastomas (as measured by intensity of immunoreactivity) has been correlated with poor patient prognosis. ${ }^{18}$ Thus, it is possible that JCV induction of medulloblastomas (as demonstrated by the findings of $\mathrm{T}$ antigen positivity and p53 overexpression) might serve as a prognostic indicator for patient survival following diagnosis.

Although immunohistochemistry detected nuclear labelling for $\mathrm{pRb}$ in five of the eight medulloblastomas in our study, the percentage of staining was significantly greatest in those tumours that showed $\mathrm{T}$ antigen and p53 expression. The observed immunoreactivity of antibodies to the $\mathrm{Rb}$ related proteins p107 and $\mathrm{Rb} 2 / \mathrm{p} 130$ in most of the $\mathrm{T}$ antigen positive cases was also significant. These findings are not unexpected because $\mathrm{pRb}$ staining has been described previously in medulloblastomas. ${ }^{35}$ The interpretation of these data is less obvious than that for $\mathrm{p} 53$. Although the Rb gene does not appear to be mutated in medulloblastomas, ${ }^{36} \mathrm{pRb}$ is integral to polyomavirus tumour induction. Binding of a product of the polyoma early region-small $\mathrm{T}$ antigen - to $\mathrm{pRb}$ is an important factor in the anti-apoptotic activities integral to polyoma tumour formation. ${ }^{37}$ Transgenic mice bearing SV40 T antigen genes deficient in $\mathrm{pRb}$ binding regions fail to develop the choroid plexus tumours found in other SV40 $\mathrm{T}$ antigen transgenics. ${ }^{38}$ In addition, $\mathrm{T}$ antigen $-\mathrm{pRb}$ complex formation has been reported to occur in human medulloblastomas. ${ }^{39}$ However, one should be wary of extending observations based on $\mathrm{pRb}$ immunoreactivity in tissue sections. Although antibodies to $\mathrm{pRb}$ stain some normal human tissues, such as respiratory epithelium, lung tumours derived from this epithelium often show little or no immunoreactivity. ${ }^{27}$ In addition, reports of $\mathrm{pRb}$ immunoreactivity in human glial tumours show a variable percentage of positive cells, perhaps depending on the number of wild-type $\mathrm{Rb}$ alleles retained by the neoplasm. ${ }^{39}{ }^{40}$ Nonetheless, the finding of immunoreactivity for $\mathrm{pRb}$ and the $\mathrm{Rb}$ family of proteins within these tumours suggests that associations with $\mathrm{T}$ antigen and/or regulation of protein expression independent of $\mathrm{T}$ antigen might play a role in the evolution of medulloblastomas.

In summary, our study has demonstrated that medulloblastomas that express polyomavirus $\mathrm{T}$ antigen are also likely to demonstrate high expression of both p53 and the Rb family of proteins. p53 and pRb may also be expressed in the same cells as $\mathrm{T}$ antigen. The possibility that these findings represent an association of $\mathrm{T}$ antigen with these proteins and the role that such an interaction might play in the development of these tumours should receive further consideration.

We would like to thank Ms C Shriver for editorial assistance, Dr LB Rorke (Department of Pathology, Children's Hospital of Philadelphia) for intellectual input, and E Gracely (Department of Biostatistics, MCP/ HU) for biostatistical advice. This work was supported by PHS grant NS36466 to KK.

1 Davis FG, Preston-Martin S. Epidemiology: incidence and survival. In: Bigner DD, McLendon RE, Bruner JM, eds. Russell and Rubenstein's pathology of tumors of the nervous system, 6th ed. New York: Oxford University Press, 1998:5-45.

2 Molenaar WM, Trojanowski JQ. Primitive neuroectodermal tumors of the central nervous system in childhood: tumor biological aspects. Crit Rev Oncol Hematol 1994:17:1-25.

3 Hart MN, Earl KM. Primitive neuroectodermal tumors of the brain in children. Cancer 1973;32:890-7.

4 Rorke LB. The cerebellar medulloblastoma and its relationship to primitive neuroectodermal tumors. 7 Neuropathol Exp to primitive neuroect

5 Provias JP, Becker LE. Cellular and molecular pathology of medulloblastoma. $\mathcal{F}$ Neurooncol 1996;29:35-43.

6 Walker DL, Padgett BL, ZuRhein GM, et al. Human papoWalker DL, Padgett BL, ZuRhein GM, et al. Human papo-
vavirus (JC): induction of brain tumors in hamsters. Science 1973;181:674-6.

7 Zhen HN, Zhang X, Bu XY, et al. Expression of the simian virus 40 large $\mathrm{T}$ antigen (Tag) and formation of tag-p53 and tag-pRb complexes in human brain tumors. Cancer 1999;68:2124-32.

8 Frisque RJ, White FA, III. The molecular biology of JC virus, causative agent of progressive multifocal leukoenTotowa, New Jersey, USA: Humana Press, 1992:26-160.

Franks RR, Rencic A, Gordon J, et al. Formation of undifferentiated mesenteric tumors in transgenic mice expressing human neurotropic polyomavirus early protein. Oncogene 1996;12:2573-8.

10 Krynska B, Otte J, Franks R, et al. Human ubiquitous JCV (CY) T-antigen gene induces brain tumors in experimental animals. Oncogene 1999;18:39-46.

11 Khalili K, Krynska B, Del Valle L, et al. Medulloblastomas and the human neurotropic polyoma virus JC virus. Lancet 999;353:1152-3.

12 Krynska B, Del Valle L, Croul S, et al. Detection of human neurotropic JC virus DNA: sequence and expression of the viral oncogenic protein in pediatric medulloblastomas. Proc Natl Acad Sci U S A 1999;96:11519-24

13 Bollag B, Chuke WF, Frisque RJ. Hybrid genomes of the polyomaviruses JC virus, BK virus, and simian virus 40 : identification of sequences important for efficient transformation. I Virol 1989;63:863-72.

14 Krynska B, Gordon J, Otte J, et al. Role of cell cycle regulators in tumor formation in transgenic mice expressing the
human neurotropic virus, JCV, early protein. 7 Cell Biochem 1997;67:223-30.

15 Major EO, Traub RG. JC virus T protein during productive infection in human fetal brain and kidney cells. Virology 1986;148:221-5.

16 Rencic A, Gordon J, Otte J, et al. Detection of JC virus DNA sequence and expression of the viral oncoprotein, tumor antigen, in brain of immunocompetent patient with ligoastrocytoma. Proc Natl Acad Sci U S A 1996;93:73527.

17 Ressetar HG, Prakash O, Frisque RJ, et al. Expression of viral T-antigen in pathological tissues from transgenic mice carrying JC-SV40 chimeric DNAs. Mol Chem Neuropathol 1993;20:59-79.

18 Jaros E, Lunec J, Perry RH, et al. p53 overexpression defines neuroectodermal tumors with poor prognosis. Cancer Res 1993;51:639-43

19 Adesina AM, Nalbantoglu J, Cavanee WK. p53 gene mutation and mdm 2 gene amplification are uncommon in medulloblastoma. Cancer Res 1994;54:5649-51.

20 Burnett ME, White EC, Sih S, et al. Chromosome arm 17p deletion analysis reveals molecular genetic heterogeneity in supratentorial and infratentorial primitive neuroectodermal tumors of the central nervous system. Cancer Genet mal tumors of the cent

21 Cogen PH, McDonald JD. Tumor suppressor genes and medulloblastoma. F Neurooncol 1996;29:103-12.

22 Nozaki M, Tada M, Matsumoto R, et al. Rare occurrence of inactivating $\mathrm{p} 53$ gene mutations in primary non-astrocytic tumors of the central nervous system: reappraisal by yeast functional assay. Acta Neuropathol (Berl) 1998;95:291-6.

23 Dyson N, Bernards R, Friend S, et al. Large T-antigens of many polyoma viruses are able to form complexes with the retinoblastoma protein. F Virol 1990;64:1353-6.

24 Hiebert SW, Chellappan SP, Horowitz JM, et al. The interaction of RB with E2F coincides with an inhibition of the transcriptional activity of E2F. Genes Dev 1992;6:177-85.

25 Johnson DG, Schwarz JK, Cress WD, et al. Expression of transcription factor $\mathrm{E} 2 \mathrm{~F} 1$ induces quiescent cells to enter $\mathrm{S}$ phase. Nature 1993;365:349-52.

26 Ludlow JW. Interactions between SV40 large-tumor antigen and the growth suppressor proteins $\mathrm{pRb}$ and $\mathrm{p} 53$. FASEB $\mathcal{F}$ 1993;7:866-71.

27 Baldi A, Esposito V, DeLuca A, et al. Differential expression of the retinoblastoma gene family members $\mathrm{pRb} / \mathrm{p} 105$,
$\mathrm{p} 107$, and pRb2/p130 in lung cancer. Clin Cancer Res 1996;2:1239-45. 
28 Padgett BL, Walker DL. Prevalence of antibodies in human sera against JC virus, an isolate from a case of progressive sera against JC virus, an isolate from a case of progressive
mulitifocal leukoencephalopathy. $\mathcal{F}$ Infect Dis 1973;127: mulitifocal

29 Neel JV, Major EO, Awa AA, et al. Hypothesis: "rouge cell"type chromosomal damage in lymphocytes is associated with infection with the JC human polyoma virus and has implications for oncopoiesis. Proc Natl Acad Sci US A 1996;93:2690-5.

30 ZuRhein GM. Studies of JC virus-induced nervous system tumors in the Syrian hamsters: a review. In: Sever JL, Madden DL, eds. Polyomavirus and human neurological diseases. 1983:205-21.

31 Bigner SH, McLenBigdon RE, Fuchs $\mathrm{H}$, et al. Chromosomal characteristics of childhood brain tumors. Cancer Genet Cytogenet 1997;97:125-34.

32 Pietsch T, Koch A, Wiestler OD. Molecular genetic studies in medulloblastomas: evidence for tumor suppressor genes at the chromosomal regions 1q31-32 and 17p13. Klin Padiatr 1997;209:150-5.

33 Ohgaki H, Eibl RH, Wiestler OD, et al. p53 mutations in nonastrocytic human brain tumors. Cancer Res 1993;51: 6202-5.
34 Karamitopoulou E, Perentes E, Diamantis I. p53 protein histochemical study with CM1 polyvalent and DO-7 monoclonal antibodies. Acta Neuropathol (Berl) 1993;85: monoclonal

35 Korshunov AG, Sycheva RV, Golanov AV. Immunohistochemical study of neoplasm-associated proteins in cerebellar medulloblastomas. Arkh Patol 1998;60:8-14.

36 Lee WH, Bookstein R, Hong F, et al. Human retinoblastoma susceptibility gene: cloning, identification and sequence. Science 1987;235:1394-9.

37 Kolzau T, Hansen RS, Zahra D, et al. Inhibition of SV40 large $\mathrm{T}$ antigen induced apoptosis by small $\mathrm{T}$ antigen. Oncogene 1999;18:5598-603.

38 Chen J, Tobin GJ, Pipas JM, et al. T-antigen mutant activities in vivo: roles of $\mathrm{p} 53$ and $\mathrm{pRb}$ binding in tumorigenesis of the choroid plexus. Oncogene 1992;7:1167-75.

39 Burns KL, Ueki K, Jhung SL, et al. Molecular genetic correlates of p16, cdk4, and pRb immunohistochemistry in glioblastomas. 7 Neuropathol Exp Neurol 1998;57:122-30.

40 Rathore A, Kamarajan P, Mathur M, et al. Simultaneous alterations of retinoblastoma and p 53 protein expression in astrocytic tumors. Pathol Oncol Res 1999;5:21-7.

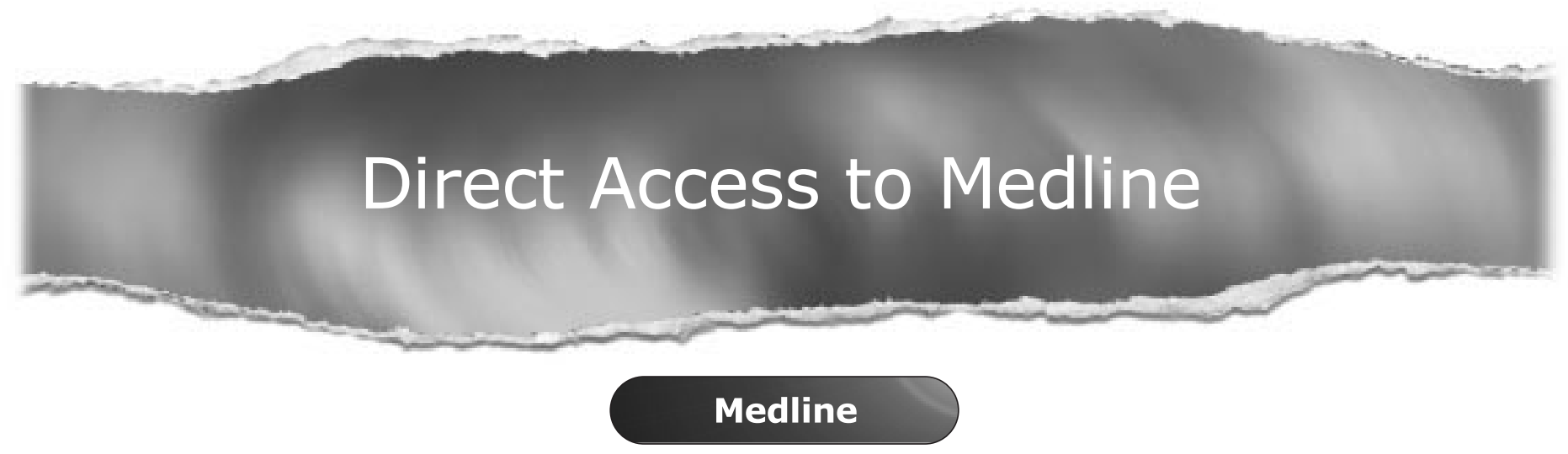

Link to Medline from the homepage and get straight into the National Library of Medicine's premier bibliographic database. Medline allows you to search across 9 million records of bibliographic citations and author abstracts from approximately 3,900 current biomedical journals.

\section{www.jclinpath.com}

